\title{
A Study of Antiulcer Activity in Cynodon dactylon Leaves Extract on Albino Rats
}

\author{
Brindha. $P^{1}$, llanchezhian. $T^{* 2}$ \\ 1Mphil student in Biochemistry, Marudu Pandiyar College, Thanjavur, Tamilnadu, India. \\ 2Assistant Professor in Biochemistry, ACPM Medical College, Dhule, Maharashtra, India. \\ *Corresponding author's E-mail: ilanbiochemistry@gmail.com
}

Received: 12-02-2021; Revised: 24-04-2021; Accepted: 30-04-2021; Published on: 15-05-2021.

\section{ABSTRACT}

Peptic ulcer is a chronic, non-malignant inflammatory disease characterized by ulceration in the upper gastro-intestinal tract (stomach and duodenum) where parietal cells are found. The aetiology of gastric ulceration is multifactorial and not clearly defined, but some predisposing factors have been implicated. This includes duration of starvation, nature of food ingested, bile reflux, lessened mucosal resistance, alteration of gastric mucosal blood flow, disruption of gastric mucosal barrier by stress, decrease in alkaline mucosal bicarbonate and mucus secretion, over dosage and or prolonged administration of non-steroidal anti-inflammatory drugs. Among numerous species of plants growing in India, Durva or taxonomically the Cynodon dactylon occupies a key position in ethno medicinal practices and traditional medical knowledge systems (Ayurveda, Unani, Nepalese, and Chinese). Durva consists of dried whole plant of Cynodon dactylon (Linn.) Pers. (Family: Poaceae), an elegant, tenacious, perennial, creeping grass growing throughout the country. In our present study, the mature green leaves of Cynodon dactylon belongs to family Poaceae were collected from in and around area of Thanjavur District, Tamil Nadu, South India. The plant was identified with the help of Manual of Tamil Nadu and Karnatic flora with standard references. From this study, it is clear that $C$. dactylon leaf extract has significant anti-ulcer activity in animal models. The extract is non-toxic even at relatively high concentrations. The anti-ulcer activity is probably due to the presence of flavonoids.

Keywords: Cynodon dactylon, antiulcer, Albino rats, flavonoids, gastric juice.

QUICK RESPONSE CODE $\rightarrow$

DOI:

10.47583/ijpsrr.2021.v68i01.014

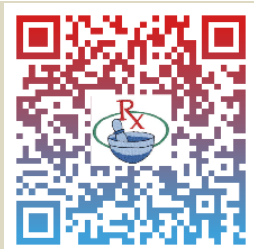

DOI link: $\underline{\text { http://dx.doi.org/10.47583/ijpsrr.2021.v68i01.014 }}$

\section{INTRODUCTION}

$\mathrm{P}$ eptic ulcer is a chronic, non-malignant inflammatory disease characterized by ulceration in the upper gastro-intestinal tract (stomach and duodenum) where parietal cells are found. The etiology of gastric ulceration is multifactorial and not clearly defined, but some predisposing factors have been implicated. This include duration of starvation, nature of food ingested, bile reflux, ${ }^{1}$ lessened mucosal resistance, ${ }^{2}$ alteration of gastric mucosal blood flow, ${ }^{3}$ disruption of gastric mucosal barrier by stress, decrease in alkaline mucosal bicarbonate and mucus secretion, over dosage and or prolonged administration of non-steroidal anti-inflammatory drugs, ${ }^{4}$ persistent infection with Helicobacter pylori, ${ }^{5}$ ZollingerEllison syndrome, and genetic factors as suggested by a higher incidence of duodenal ulcers in patients with positive family history of this disorder or blood type $0 .{ }^{6}$

In recent years, a large advance in chemical and pharmacological studies has contributed to the knowledge about new therapeutically active compounds obtained from the natural products. Cynodon dactylon occurs on almost all soil types especially in fertile soil. e.g. loamy soil. It is common in disturbed areas such as gardens, roadsides, overgrazed, trampled areas, uncultivated lands, localities with high levels of nitrogen, and is often found in moist sites along rivers. It is suitable for cultivation under dry land conditions. Cynodon dactylon plays an important role in conservation, because it prevents soil erosion. It provides good grazing, is very useful as a lawn grass and is recommended for the protection of waterways. ${ }^{7}$ When selecting a plant for pharmacological activities, four basics methods are usually followed:

A. Random choice of plant species

B. Choice based on ethnomedical use

C. Follow up of existing literature on the use of the species

D. Chemotaxonomic approaches ${ }^{8}$

Comparison of the four methods showed that the choice based on folklore has given about $32 \%$ more positive leads than other methods. Based on the second and third approach, selection of the plant has been made in the present work. In light of the above context, Cynodon dactylon were selected for the study.

The main goal of our present study has been extended to evaluate the study of anticancer activity in Cynodon dactylon which is extracted from Albino rats. 


\section{MATERIALS AND METHODS}

For the present study, the mature green leaves of Cynodon dactylon belongs to family Poaceae were collected from in and around area of Thanjavur District, Tamil Nadu, South India. The plant was identified with the help of Manual of Tamil Nadu and Karnatic flora with standard references.

\section{Preparation of leaf powder}

The Cynodon dactylon was collected washed, cut into small pieces and dried at room temperature (39o C) for two weeks and made into powder by using mixture for further analysis.

\section{Preparation of plant extract}

Extraction is a process, to separate or isolate the secondary metabolites from plant material. It is basically two types i.e. heat and cold extraction. Heat extraction has some advantage over cold extraction like time consistency and also no contamination by microbes. An apparatus called soxhlet did heat extraction. $100 \mathrm{~g}$ of the plant leaf powder were packed into the thimble of a soxhlet apparatus. The ratio of the plant powder and solvents were maintained at 1:4.

\section{Experimental design}

Animals are acting as good models for numerous experiments, which are carried to bring the beneficial effects on human population; this formed the basis for selection.

A group of 36 adult Swiss albino rats weighing $100-150 \mathrm{~g}$ were purchased from Rainbow institute kattumannargudi and brought to the laboratory in large sized microlon cages. Fresh dry husk was used as bed material. They were fed with commercial pellet diet from Sai Durga feed and foods, Bangalore and tap water ad-libitum. They were maintained at room temperature under standard laboratory conditions.

\section{Anti-ulcer activity}

The experimental procedures of rats $^{9}$ weighing 150$160 \mathrm{~g}$ were divided into groups of six animals each and were placed in cages with grating floor to avoid coprophagy and fasted for 48 hours allowing free access to water. One group received water $(1 \mathrm{ml} / \mathrm{kg})$ and was served as control. Ranitidine $(30 \mathrm{mg} / \mathrm{kg}$ ) was selected as standard drug and was given to a group, for comparison. For the test group, the animals were grouped into two, receiving the drug at a dose level of $200 \& 300 \mathrm{mg} / \mathrm{kg}$ body weight. Aspirin plus pylorus ligation (PL) model: 9 Ulceration in rats was induced by Aspirin suspension in $1 \%$ (CMCcarboxymethylcellulose in water was administered orally in a dose of $200 \mathrm{mg} / \mathrm{kg}$ once daily for three days. On fourth day, pylorus was ligated as per the method. ${ }^{9}$

Under light ether anesthesia, the abdomen was opened by a small mid-incision below the xiphoid process, pyloric portion of stomach was slightly lifted out and legated avoiding traction to the pylorus or damage to its blood supply. The stomach was replaced carefully and the abdomen wall closed by interrupted sutures. The test drugs (Cynodon dactylon) were administered once daily orally for two weeks. The animals were deprived of both food and water during the post-operative period. Four hours after the ligation, animals were sacrificed. Ulceration in the stomach was assessed by means of a scoring technique whereby macroscopic examination of the stomach was made using a hand lens and ulcers were scored using the method and criteria. Normal gastric mucosa was scored Nill, punctuate haemorrhage, pinpoint ulcer was scored 0.5 , one or two small hemorrhages ulcer was scored 1.0 while ulcers greater than $3 \mathrm{~mm}$ in diameters were scored. Ulcer index and percentage inhibition of ulceration were calculated by reported method. ${ }^{10}$

Ulcer index $=($ Mean degree of ulceration $X \%$ group of ulceration $) 100$

$$
\% \text { inhibition of ulceration }=\frac{(\text { Ulcer index in control }- \text { Ulcer index in test })}{\text { Ulcer index in control }} \times 100
$$

\section{Collection of gastric juice}

The stomach was excised carefully keeping the esophagus closed, opened along the greater curvature and the luminal contents were removed. ${ }^{11}$ The gastric contents were collected in a beaker and centrifuged at $1000 \mathrm{rpm}$ for 10 minutes as recommended. Gastric juice was collected from the pylorus-ligated rats. The gastric juice thus collected was centrifuged and the volume of gastric juice as well $\mathrm{pH}$ of gastric juice was measured. The sodium $\left(\mathrm{Na}^{+}\right)$and potassium $\left(\mathrm{K}^{+}\right)$ion concentration of gastric juice was carried out in flame photometer. ${ }^{12}$ Then the gastric juice was subjected to bio-chemical estimation as follows.

\section{Determination of $\mathrm{pH}$}

Supernatant of gastric juice solution containing Hydrogen ion concentrations were measured with the help of $\mathrm{pH}$ meter. The reading of $\mathrm{pH}$ was read in electronic display.

\section{Estimation of gastric content}

\section{Principle}

The total gastric content is estimated based on its acid content, which is found by titrating the gastric juice obtained against sodium hydroxide using Topfer's reagent as indicator.

\section{Reagents}

1. $0.01 \mathrm{~N}$ sodium hydroxide : Dissolved $0.4 \mathrm{~g}$ of $\mathrm{NaOH}$ in $1000 \mathrm{ml}$ of water

2. Topfer's reagent

\section{Procedure}

The total volume of gastric content was measured. The gastric content were centrifuged at $1000 \mathrm{rpm}$ for $10 \mathrm{~min}$. one $\mathrm{ml}$ of the supernatant liquid was pipette out and diluted to $10 \mathrm{ml}$ with distilled water. The solution was 
titrated against $0.01 \mathrm{~N} \mathrm{NaOH}$ using Topfer's reagent an indicator, to the endpoint when the solution turned to orange colour. The volume of $\mathrm{NaOH}$ needed was taken as corresponding to the free acidity. Titration was further continued till the solution regained pink colour. The volume of $\mathrm{NaOH}$ required was noted and was taken as corresponding to the total acidity. ${ }^{13}$

$$
\text { Acidity }(\mathrm{mEg} / \mathrm{l})=\frac{\text { Volume of } \mathrm{NaOH} \times \text { Normality }}{0.1} \times 100
$$

\section{Estimation of pepsin}

For each determination four tubes (1) and (2) containing $5 \mathrm{ml}$ of substrate, (3) and (4) containing $10 \mathrm{ml}$ TCA was placed in the water bath at $37^{\circ} \mathrm{C}$. The gastric juice was mixed with an equal volume of $\mathrm{HCl}$ at $\mathrm{pH} 2.1$, warmed to $37^{\circ} \mathrm{C}$ and added $1 \mathrm{ml}$ of mixture to each tube (1) and (4), incubated for 15 minutes and at the end mixed the contents of tube (1) with tube (3) and allowed to stand in the bath for about 4 minutes. Contents of tube (1) and tube (3) give test and contents of tube (2) and tube (4) gives blank. Both the contents were filtered after 25-30 minutes, $2 \mathrm{ml}$ of filtrate was pipetted into $10 \mathrm{ml}$ of $\mathrm{NaOH}$, mixed by gentle rotation, then $1 \mathrm{ml}$ of phenol was added and again mixed by gentle rotation. After $30 \mathrm{~min}$, intensity of colour was measure at $680 \mathrm{~nm}$ in Systronics UV-VIS spectrophotometer-18.

The difference between test and blank gives a measure of peptic activity. As standard, mixed $2 \mathrm{ml}$ of freshly prepared phenol solution containing $50 \mu \mathrm{g} / \mathrm{ml}$ with $10 \mathrm{ml}$ of $\mathrm{NaOH}$ and $1 \mathrm{ml}$ of phenol reagent was added. After 5-10 minutes, the colour intensity was measured at $680 \mathrm{~nm} .^{14}$

\section{Estimation of Sodium $\left(\mathrm{Na}^{+}\right)$and Potassium $\left(\mathrm{K}^{+}\right)$ion concentration in gastric juice}

The estimation for sodium and potassium ions was carried out using Systronics mediflame 127 - flame photometer.

\section{Preparation of stock solution}

Sodium stock solution was prepared by dissolving $2.542 \mathrm{~g}$ $\mathrm{NaCl}$ in 1 liter of distilled water. It contains $1 \mathrm{mg} \mathrm{Na}$ per $\mathrm{ml}$ (i.e. 1000 ppm). Stock solution was diluted to give four solutions containing $10,5,2.5$ and 1 ppm of sodium ions.

Potassium stock solution was prepared by dissolving $1.909 \mathrm{~g} \mathrm{KCl}$ in 1 liter of distilled water. It contains $1 \mathrm{mg}$ potassium per $\mathrm{ml}$ (i.e. $1000 \mathrm{ppm}$ ). Stock solution was diluted to give four solutions containing 20, 10, 5 and 2 ppm of potassium ions.

\section{Procedure}

For sodium and potassium, the flame intensity corresponding to the concentration of stock solution was noted using appropriate filters. The results were plotted in a graph. The flame intensity of the gastric juice was noted. The concentration of sodium and potassium ions was calculated from the graph. The results are expressed in terms of $\mathrm{mg} / \mathrm{I}^{14}$

\section{Estimation of Total protein}

The dissolved protein in gastric juice was estimated in the alcoholic precipitate obtained by adding $90 \%$ alcohol with gastric juice in 9:1 ratio. Then $0.1 \mathrm{ml}$ of alcoholic precipitate of gastric juice was dissolved in $1 \mathrm{ml}$ of $0.1 \mathrm{~N}$ $\mathrm{NaOH}$ and from this $0.05 \mathrm{ml}$ was taken in another test tube, to this $4 \mathrm{ml}$ of alkaline mixture was added and kept for $10 \mathrm{~min}$. Then $0.4 \mathrm{ml}$ of phenol reagent was added and again $10 \mathrm{~min}$ was allowed for colour development. Reading was taken against blank prepared with distilled water at $610 \mathrm{~nm}$ in Systronics UV-VIS spectrophotometer180. The protein content was calculated from standard curve prepared with bovne albumin and was expressed in terms of $\mu \mathrm{g} / \mathrm{ml}$ of gastric juice. ${ }^{15}$

\section{Estimation of sialic acid}

To $0.5 \mathrm{ml}$ of the hydrolysate in $0.1 \mathrm{~N} \mathrm{H}_{2} \mathrm{SO}_{4}, 0.2 \mathrm{ml}$ of sodium periodate was added and mixed thoroughly by shaking. A time of $20 \mathrm{~min}$ was allowed to elapse before addition of $1 \mathrm{ml}$ of sodium arsenite solution to this mixture. The brown colour produced disappeared after shaking. Then $3 \mathrm{ml}$ of thibarbituric acid was added and the mixture was heated in boiling water bath for 15 minutes. After cooling the tubes, $4.5 \mathrm{ml}$ of cyclohexanone was added and through shaking was done for 15 seconds till all the colour was taken up by the cyclohexanone supernatant. The mixture was centrifuged to get a clear pink layer of cyclohexanone. This supernatant was pipeted out and intensity of colour was measured in Systronics UV-VIS spectrophotometer- 180 at 550nm. The sialic acid content of the sample was determined from the standard curve of sialic acid and has been expressed in terms of $\mu \mathrm{g} / \mathrm{ml}$ of gastric juice. ${ }^{16}$

\section{RESULTS}

The present study was carried out to evaluate the antiulcer activity of Cynodon dactylon against Aspirin induced toxicity in albino rats. The effectiveness of this medicinal plant was screened by assessing biochemical changes of different groups of experimental animals. The results were expressed as mean \pm standard deviation.

The herbal powder of $C$. dactylon was taken in a soxhlet apparatus and refluxed serially using ethanol solvent system depending upon the polarity. The extracts of organic solvent system were transferred separately in previous weighted beaker the weight of the sample was calculated. Weight and character of the sample was found to be more in ethanol leaching out of the compounds. 
Table 1: Effect of Cynodon dactylon on ulcer index lesions in aspirin treated pylorus ligated rats

\begin{tabular}{|c|l|c|c|c|}
\hline S. No & Treatment group & Ulcer index & $\mathbf{p H}$ & Protein $(\boldsymbol{\mu g} / \mathrm{dl})$ \\
\hline $\mathbf{1}$ & Control & $1.01 \pm 0.20$ & $4.2 \pm 0.06$ & $350 \pm 25.8$ \\
\hline $\mathbf{2}$ & Aspirin $(200 \mathrm{mg} / \mathrm{kg})$ & $2.80 \pm 0.35$ & $2.5 \pm 0.02$ & $495 \pm 29.2$ \\
\hline $\mathbf{3}$ & Cynodon dactylon $(200 \mathrm{mg} / \mathrm{kg})$ & $1.35 \pm 0.02$ & $3.3 \pm 2.04$ & $390 \pm 22.0$ \\
\hline $\mathbf{4}$ & Cynodon dactylon $(300 \mathrm{mg} / \mathrm{kg})$ & $1.20 \pm 0.15$ & $3.7 \pm 3.19$ & $340 \pm 14.5$ \\
\hline $\mathbf{5}$ & Ranitidine $(30 \mathrm{mg} / \mathrm{kg})$ & $1.12 \pm 0.03$ & $3.8 \pm 0.03$ & $311 \pm 34.7$ \\
\hline
\end{tabular}

Table 2: Effect of Cynodon dactylon on sodium and potassium ion concentration in aspirin treated pylorus ligated rats

\begin{tabular}{|c|l|c|c|}
\hline S. No & Treatment group & Sodium (mEq/L) & Potassium (mEq/L) \\
\hline $\mathbf{1}$ & Control & $140 \pm 0.22$ & $16 \pm 6.04$ \\
\hline $\mathbf{2}$ & Aspirin $(200 \mathrm{mg} / \mathrm{kg})$ & $76 \pm 2.02$ & $6 \pm 2.06$ \\
\hline $\mathbf{3}$ & Cynodon dactylon $(200 \mathrm{mg} / \mathrm{kg})$ & $125 \pm 2.24$ & $12 \pm 0.28$ \\
\hline $\mathbf{4}$ & Cynodon dactylon $(300 \mathrm{mg} / \mathrm{kg})$ & $145 \pm 0.17$ & $14 \pm 2.04$ \\
\hline $\mathbf{5}$ & Ranitidine $(30 \mathrm{mg} / \mathrm{kg})$ & $156 \pm 1.06$ & $14 \pm 1.07$ \\
\hline
\end{tabular}

Table 3: Effect of Cynodon dactylon on gastric secretion, acidity and pepsin activity in aspirin treated pylorus ligated rats

\begin{tabular}{|c|l|c|c|c|c|}
\hline $\begin{array}{l}\text { S. } \\
\text { No }\end{array}$ & \multicolumn{1}{|c|}{ Treatment group } & $\begin{array}{c}\text { Volume of gastric } \\
\text { juice }(\mathbf{m E q} / \mathbf{L})\end{array}$ & $\begin{array}{c}\text { Free acidity } \\
(\mathbf{m E q} / \mathbf{L})\end{array}$ & $\begin{array}{c}\text { Total acidity }(\mathbf{m} \\
\mathbf{E q} / \mathbf{L})\end{array}$ & $\begin{array}{c}\text { Pepsin activity } \\
(\boldsymbol{\mu g} / \mathbf{m l})\end{array}$ \\
\hline $\mathbf{1}$ & Control & $105.5 \pm 1.14$ & $13.1 \pm 23.3$ & $60.30 \pm 10.9$ & $9.1 \pm 0.99$ \\
\hline $\mathbf{2}$ & Aspirin $(200 \mathrm{mg} / \mathrm{kg})$ & $185.2 \pm 0.82$ & $17.1 \pm 5.7$ & $46.30 \pm 13.8$ & $6.7 \pm 1.70$ \\
\hline $\mathbf{3}$ & C.dactylon $(200 \mathrm{mg} / \mathrm{kg})$ & $139.5 \pm 2.02$ & $13.8 \pm 1.2$ & $53.25 \pm 0.02$ & $7.75 \pm 1.17$ \\
\hline $\mathbf{4}$ & C.dactylon $(300 \mathrm{mg} / \mathrm{kg})$ & $118.2 \pm 0.08$ & $13.2 \pm 0.6$ & $55.32 \pm 0.04$ & $8.01 \pm 2.19$ \\
$\mathbf{5}$ & Ranitidine $(30 \mathrm{mg} / \mathrm{kg})$ & $112.2 \pm 0.87$ & $12.3 \pm 1.6$ & $55.5 \pm 3.50$ & $9.05 \pm 0.7$ \\
\hline
\end{tabular}

\section{DISCUSSION}

Cynodon dactylon has been reported to have multidimensional pharmacological profile like antidiabetic, antihyperlipidemic, antiperoxidative antimicrobial, antiasthamatic and traditionally being used to cure rheumatism, conjunctivitis and gout. The present work has been undertaken to establish the various pharmacognostical parameters, which could serve as a measure of authentication and quality control of the crude drug. Various parameters like morphology, microscopy, chemo-microscopy, histochemistry, physico- chemical constants, numerical, fluorescence, secondary metabolites profiles of the leaves were studied and the salient diagnostic features were documented. Treatment of ulcers is a global problem and needs to be studied in detail. Based on these facts the present study was conducted to look at the antiulcer effects of $C$. dactylon leaf extract and flavonoid compounds of quercetin. Gastric ulcers were produced by oral administration of aspirin in albino rats. $C$. dactylon leaf extract quercetin and silver nanoparticle were given to see the response and this effect was compared with the ulcer healing drugs in market commonly used by ulcer patients.
The result of phytochemical screening of the aqueous and alcoholic extracts of $C$. dactylon revealed the presence of alkaloids, flavonoids, phytosterols, tannins and phenols. The plant extract of $C$. dactylon used for the present work was choosing on the basis of their medicinal values. The natural plant parts are having a wide range of medicinal properties like hepatoproductive, antimicrobial, diuretic, emollient, febrifuge, narcotic, purgative and sedative. Previous study in the naturally the ethanolic extracts of $C$. dactylon were subjected for phytochemical analysis. Phytochemical screening of the crude extract revealed the presence of alkaloids, cardiac glycosides, terpenoids, saponins, tannin, flavonoids and steroids but reducing sugars, carbonyl (aldehyde) and Phlobatanin show negative results.

The natural plant parts are having a wide range of medicinal properties like hepatoproductive, antimicrobial, diuretic, emollient, febrifuge, narcotic, purgative and sedative. Previous study in the naturally the ethanolic extracts of $C$. dactylon were subjected for phytochemical analysis. Phytochemical screening of the crude extract revealed the presence of alkaloids, cardiac glycosides, terpenoids, saponins, tannin, flavonoids and steriods but 
reducing sugars, carbonyl (aldehyde) and Phlobatanin show negative results. ${ }^{17}$

In the present investigation alcoholic and aqueous extract of the plant showed the presence of alkaloids, flavonoids, phytosterols, tannins and phenols. The production of secondary metabolites by the plant cells growing in culture have been confirmed by several scientists. He observed the production of indole alkaloids, ajmalicine in cell suspension culture of Catharanthus roseus. ${ }^{18}$

C. dactylon used in the study have been found to be effective against aspirin pylorus ligation model. It is evident from the results that these drugs produce reduction in the intensity of gastric ulceration as observed from reduced ulcer index in the drug treated groups. However, inconsistent results were obtained as regards to other parameters such as volume of gastric acid secretion, free and total acidity and pepsin activity. C. dactylon and Ranitidine showed reduction in volume of gastric secretion without affecting pepsin activity of gastric juice. These findings go parallel with the reported that calcium is not involved in the physiological secretion of pepsin. It appears that calcium may be involved only in acid secretary activity of GI tract but not in pepsin activity. ${ }^{19}$

Based upon above discussion, the protective effect of these drugs may be attributed to some reason other than their antisecretory activity. Along with the gastric acid secretion, reflex or neurogenic effects have also been proposed to play some role in the formation of gastric ulcers in $\mathrm{PL}$ model. ${ }^{20}$ It is a well known fact that gastric secretion is under vagal controls. ${ }^{21}$ A possible central effect of verapamil interfering with any ulcerogenic action in triggering vagal outflow cannot be ruled out, since vagal overactivity appears to contribute substantially to any stress ulcer formation. ${ }^{22}$ It has been postulated that histamine plays a mediating role in the gastric acid secretion stimulated by gastrin, vagal excitation and cholinergic agents. ${ }^{23}$

\section{CONCLUSION}

From this study, it is clear that $C$. dactylon leaf extract have significant anti-ulcer activity in animal models. It has mucoprotective activity and gastric anti-secretary when compared with that of reference drug Ranitidine. The extract is non-toxic even at relatively high concentrations. The anti-ulcer activity is probably due to the presence of flavanoids. Further studies are being carried out to characterize and explore the biological activity of the compounds present in the extract.

\section{REFERENCES}

1. Gerald, MC. 1981. Pharmacology: An introduction to drugs, $2^{\text {nd }}$ ed. Prentice- Hall Inc; New Jersey: 487-499.

2. Cho, $\mathrm{CH}$ and $\mathrm{CW}$. Ogle. The Pharmacological differences and similarities between stress and ethanol-induced mucosal damage. Life Sci., 1992;51: 1833-1842.
3. Guidobono, F., Pagani, F., Ticozzi, C., Sibilica, V., Pecile, $A$ and $C$. Netti. Protection by Amylin of gastric erosions induced by indomethacine or ethanol in rats. $\mathrm{Br}$. J. Pharmacol., 1997; 120: 581-586.

4. Tanaka, H., Shuto, K and N. Nakamizo. Exacerbation of acetic acid induced by Non-steroidal antiinflammatory drugs in rats. Jap. J. Pharmcol., 1983; 33(2): 447-54.

5. Munson, PL., Mueller, RA and GR. Breese. Principles of pharmacology: Basic concepts and clinical applications. Chapman \& Hall, USA. 1995; pp. 10631081.

6. Coles, EH. 1986. Determination of packed cell volume In: Coles E. H. Ed, Veterinary clinical Pathology. W.B. Saunders Co; Philadelphia. pp.17-9.

7. Raghunathan, K and R. Mitra. Pharmacognosy of Indigenous Drugs, Central Council for Research in Ayurveda and Siddha, New Delhi. 1982; 1: 41-50.

8. Suffness, M and J. Douros. Drugs of plant origin. Methods in Canc. Res. 1979; 16: 73-126.

9. Shay, H., Komarou, S.A., Fels, S.S., Meranze, D., Gruenstein, M. and Siplet, H., A simple method for the uniform production of gastric ulceration in rate. J. Gastroenterol, 1945; 5: 43-51.

10. Goel, RK., Gupta, S., Shankar, R, Sanyal, AK. Antiulcerogenic effect of banana powder (Musa sapientum var. paradisica) and its effect on mucosal resistance. J Ethnopharmacol., 1986;18:33-44.

11. Raji Y, Ogunwande IA, Osadebe CA, John G. Effects of Azadirachta indica extract on gastric ulceration and acid secretion in rats. J Ethnopharmacol., 2004; 90(1):167-70

12. Jain, S.M. and Santani, D.D., Peptic ulcer disease and status of current drug therapy. Indian Drugs, 1994; 31(9): 395-400.

13. Jeffer, G.H. Bassett, J. Mendham, J. and Denney. R.C. 1991. Vogel's textbook of quantitative chemical analysis. $5^{\text {th }}$ edn. Longman Scientific \& Technical, London.

14. Debnath, P.K. Gode, K.D. Govinda, D. and Sanyal, A.K., Effect of propranolol on gastric secretion in albino rate. Brit. J. Pharmacol, 1974; 52: 213-216.

15. Lowry $\mathrm{OH}$, Rosenbrough NJ, Farr AL, Randall RJ. Protein measurement with folin phenol reagent. J Biol Chem., 1951; 193: 265-275.

16. Warren $\mathrm{L}$. The thiobarbituric acid assay of sialic acids, J Biol Chem., 1959; 234: 1971-1975.

17. Venkatesan, D, C.M. Karrunakarn, S. Selva Kumar and P.T. Palani Swamy. Identification of Phytochemical Constituents of Aegle marmelos Responsible for antimicrobial Activity against Selected Pathogenic Organisms. Ethnobotanical Leaflets 2009; 13: 1362- 
72.

18. Ramawat, K.G. 1999. Secondary Metabolites in Biotechnology, Oxford - IBH Pub, New Delhi.

19. Brage R, Cortijo J, Esplugues J, Esplugues JV, MartiBonmati E, Rodriguez C. Effects of calcium channel blockers on gastric emptying and acid secretion of rat in vivo. Br J Pharmacol., 1986; 89: 627-633.

20. Anichkov SV, Zavodskaua IS, Moreva EV, Korkhov W. Effect of dihydroxyphenylalanin (DOPA) upon development of experimental neurogenic gastric ulcers. In: Pfeiffer CJ, ed. Peptic ulcer. Copenhagen:
Munkgaard, 1971;307-I1.

21. Brodie DA. The mechanism of gastric hyperacidity produced by pyloric ligation in the rat. Am J Dig Dis., 1966; 11: 231-241.

22. Ogle $\mathrm{CW}$, Cho $\mathrm{CH}$, Tong $\mathrm{MC}$, Koo MWL. The influence of verapamil on the gastric effect of stress in rats. Eur J Pharmacol., 1985; 112:399-404.

23. Parmar NS, Ghosh MN. Gastric antiulcer activity of (+) cyanidanol-3, a histidine decarboxylase inhibitor. Eur Pharmacol., 1981; 69:25-32.

Source of Support: None declared.

Conflict of Interest: None declared.

For any question relates to this article, please reach us at: editor@globalresearchonline.net New manuscripts for publication can be submitted at: submit@globalresearchonline.net and submit_ijpsrr@rediffmail.com 